\title{
Medulloblastoma and ependymoma cells display increased levels of 5- carboxylcytosine and elevated TET1 expression
}

\author{
Ashley Ramsawhook ${ }^{1}$, Lara Lewis ${ }^{1}$, Beth Coyle $2^{2^{*}}$ and Alexey Ruzov ${ }^{1 *}$ (i)
}

\begin{abstract}
Background: Alteration of DNA methylation (5-methylcytosine, $5 \mathrm{mC}$ ) patterns represents one of the causes of tumorigenesis and cancer progression. Tet proteins can oxidise $5 \mathrm{mC}$ to 5-hydroxymethylcytosine $(5 \mathrm{hmC}), 5$ formylcytosine and 5-carboxylcytosine (5caC). Although the roles of these oxidised forms of $5 \mathrm{mC}$ (oxi-mCs) in cancer pathogenesis are still largely unknown, there are indications that they may be involved in the mechanisms of malignant transformation. Thus, reduction of $5 \mathrm{hmC}$ content represents an epigenetic hallmark of human tumours, and according to our recent report, $5 \mathrm{caC}$ is enriched in a proportion of breast cancers and gliomas. Nevertheless, the distribution of oxi-mCs in paediatric brain tumours has not been assessed.

Findings: Here, we analyse the global levels and spatial distribution of $5 \mathrm{hmC}$ and $5 \mathrm{caC}$ in four brain tumour cell lines derived from paediatric sonic hedgehog (SHH) pathway-activated medulloblastomas (Daoy and UW228-3) and ependymomas (BXD-1425EPN and DKFZ-EP1NS). We show that, unlike HeLa cells, the paediatric tumour cell lines possess both $5 \mathrm{hmC}$ and $5 \mathrm{caC}$ at immunochemically detectable levels and demonstrate that both modifications display high degrees of spatial overlap in the nuclei of medulloblastomas and ependymomas. Moreover, although 5hmC levels are comparable in the four brain tumour cell lines, $5 \mathrm{caC}$ staining intensities differ dramatically between them with highest levels of this mark in a subpopulation of DKFZ-EP1NS cells. Remarkably, the $5 \mathrm{caC}$ enrichment does not correlate with $5 \mathrm{hmC}$ levels and is not associated with alterations in thymine DNA glycosylase (TDG) expression in SHH medulloblastoma and ependymoma cell lines but corresponds to elevated levels of TET1 transcript in UW228-3 and DKFZ-EP1NS cells.

Conclusions: We demonstrate that both $5 \mathrm{caC}$ enrichment and elevated TET1 expression are observed in SHH medulloblastomas and ependymomas. Our results suggest that increased Tet-dependent $5 \mathrm{mC}$ oxidation may represent one of the epigenetic signatures of cancers with neural stem cell origin and, thus, may contribute to development of novel approaches for diagnosis and therapy of the brain tumours.
\end{abstract}

Keywords: DNA methylation, 5-hydroxymethylcytosine, 5-carboxylcytosine, Paediatric brain tumours, Medulloblastoma, Ependymoma, Immunohistochemistry

\footnotetext{
* Correspondence: beth.coyle@nottingham.ac.uk;

Alexey.Ruzov@nottingham.ac.uk

${ }^{2}$ Children's Brain Tumour Research Centre, School of Medicine, QMC,

University of Nottingham, Nottingham NG7 2UH, UK

'Division of Cancer and Stem Cells, School of Medicine, Centre for

Biomolecular Sciences, University of Nottingham, University Park, Nottingham

NG7 2RD, UK
}

(c) The Author(s). 2017 Open Access This article is distributed under the terms of the Creative Commons Attribution 4.0 International License (http://creativecommons.org/licenses/by/4.0/), which permits unrestricted use, distribution, and reproduction in any medium, provided you give appropriate credit to the original author(s) and the source, provide a link to the Creative Commons license, and indicate if changes were made. The Creative Commons Public Domain Dedication waiver (http://creativecommons.org/publicdomain/zero/1.0/) applies to the data made available in this article, unless otherwise stated. 


\section{Findings}

\section{Background}

Alterations of both DNA methylation (5-methylcytosine, $5 \mathrm{mC}$ ) patterns and chromatin structure are anticipated to be of key importance for the initiation and progression of human cancer [1-3]. Genomic distribution of $5 \mathrm{mC}$ undergoes dramatic transformation during tumorigenesis resulting in aberrant patterns of gene expression due to hypermethylation of promoters of tumour suppressor genes and to hypomethylation of oncogene's promoters $[3,4]$. Thus, malignant transformation is determined by both de novo methylation and demethylation of specific genomic regions $[4,5]$.

The molecular mechanisms of active DNA demethylation were largely obscure until a number of studies demonstrated that Tet (ten-eleven translocation) proteins (Tet1/2/3) can oxidise $5 \mathrm{mC}$ to 5-hydroxymethylcytosine (5hmC), 5-formylcytosine (5fC) and 5-carboxylcytosine $(5 \mathrm{caC})[6-8]$. Remarkably, apart from their potential roles in the regulation of transcription, these oxidised forms of $5 \mathrm{mC}$ (oxi-mCs) may also serve as intermediates in active and passive demethylation mechanisms [9-12]. Thus, both $5 \mathrm{fC}$ and $5 \mathrm{caC}$ can be recognised and excised from DNA by thymine DNA glycosylase (TDG) followed by incorporation of non-modified cytosine into the generated abasic site by the components of base-excision repair (BER) pathway $[7,8,11]$. Despite the putative involvement of the oxi$\mathrm{mCs}$ in the mechanisms of DNA demethylation, the roles of these epigenetic modifications in cancer initiation and progression are currently mostly unclear [13]. However, there is a growing body of experimental evidence suggesting that both oxi-mCs and Tet proteins are important for the processes of malignant transformation $[5,13]$. Thus, it is currently widely acknowledged that depletion of $5 \mathrm{hmC}$ represents an epigenetic hallmark of a number of human cancers [14-17]. In addition, in our recent study, we, rather unexpectedly, found that $5 \mathrm{caC}$ is enriched in a proportion of breast cancers and gliomas [18].

Potential biological functions of Tet-dependent $5 \mathrm{mC}$ oxidation have been extensively studied in adult brain tumours during several recent years [19-21]. However, neither the oxi-mCs content nor the expression levels of Tet proteins have been assessed in paediatric brain tumours. Nevertheless, a range of tumour suppressors and other genes involved in cancer pathogenesis are aberrantly methylated in both paediatric medulloblastomas and ependymomas implying that DNA (de)methylation plays important role in initiation and/or progression of these types of cancer [22].

In the present study, we aimed to determine the global levels and nuclear distribution of oxi-mCs as well as the expression of TET1/2/3 and TDG transcripts in tumour cell lines derived from paediatric medulloblastomas and ependymomas.

\section{Methods}

Cell lines and cell culture

BXD-1425EPN [23], DKFZ-EP1NS [24] and HeLa cells were cultured in Dulbecco's modified Eagles medium (DMEM) (Gibco, Life Technologies) supplemented with $10 \%$ foetal bovine serum and $1 \%$ penicillin/streptomycin. Daoy [25] cells were cultured in MEM/EBSS supplemented with $10 \%$ heat-inactivated foetal bovine serum, sodium pyruvate, non-essential amino acids, $2 \mathrm{~mL}$ glutamine, $100 \mathrm{~g} / \mathrm{mL}$ streptomycin and $100 \mathrm{U} / \mathrm{mL}$ penicillin. The UW228-3 [26] cell line was cultured in DMEM/ F12 supplemented with $10 \%$ heat-inactivated foetal bovine serum, $2 \mathrm{~mL}$ glutamine, $100 \mathrm{~g} / \mathrm{mL}$ streptomycin and $100 \mathrm{U} / \mathrm{mL}$ penicillin.

\section{Immunocytochemistry, immunohistochemistry, confocal microscopy, quantification of the signal intensities and statistical analysis}

Immunochemistry, confocal microscopy and generation of 2.5XD intensity plots and intensity profiles were performed as previously described [27]. Anti-5hmC mouse monoclonal (Active Motif, 1:5000 dilution) and anti$5 \mathrm{caC}$ rabbit polyclonal (Active Motif, 1:500 dilution) primary antibodies were used for immunochemistry. Peroxidase-conjugated anti-rabbit secondary antibody (Dako) and the tyramide signal enhancement system (PerkinElmer, 1:200 dilution, 2 min of incubation with tyramide) were employed for $5 \mathrm{caC}$ detection. $5 \mathrm{hmC}$ was visualised using 555-conjugated secondary antibody (Alexafluor). Control staining without primary antibody produced no detectable signal. Paraffin-embedded formaldehyde-fixed $12.5 \mathrm{dpc}$ murine embryonic tissue was used for $5 \mathrm{caC} / 5 \mathrm{hmC}$ immunostaining of embryonic brain cells. For quantification of the $5 \mathrm{hmC}$ and $5 \mathrm{caC}$ signal intensities in multiple cells, mean values of the average intensities of eight intensity profiles were calculated for each cell line or, for DKFZ-EP1NS cells, for the populations of $5 \mathrm{caC}$-positive and $5 \mathrm{caC}$-negative cells. Statistical significance was determined by two-tailed $t$ test after assessing the variance with $F$ test.

\section{Gene expression analysis}

Expression of TET1/2/3 and TDG transcripts was analysed by quantitative PCR according to standard procedures. Gene expression was normalised by comparison to levels of GAPDH gene expression. The following primers were used:

TET1: CTTGGTATGAGTGGGAGTG and GAGCATTAAAGGTAGCAATTG; TET2: GCAAGATCTTCTTCACAG and GCATGGTTATGTATCAAGTA; TET3: CTCTGAAGTCAGAGGAGAA and GTCCAGGAAGTTGTGTTC; 


\section{TDG: CAGCTATTCCCTTCAGCA and GGAACTTCTTCTGGCATTTG; GAPDH: GATGCTGGCGCTGAGTACG and GCAGAGATGATGACCCTTTTGG.}

\section{Results}

To examine the global levels of oxi-mCs in paediatric brain tumours, we initially performed co-detection of $5 \mathrm{hmC}$ with $5 \mathrm{caC}$ in two sonic hedgehog ( $\mathrm{SHH}$ ) pathway-activated medulloblastoma (UW228-3 and Daoy) and two ependymoma (BXD-1425EPN and DKFZ-EP1NS) cell lines using a protocol for sensitive immunostaining of modified forms of cytosine that we previously developed and validated by mass spectrometry [27]. Unlike in HeLa cells where $5 \mathrm{caC}$ was undetectable by immunochemistry under our experimental conditions (Fig. 1a), we observed non-negligible levels of both $5 \mathrm{hmC}$ and $5 \mathrm{caC}$ immunostaining in all the tested medulloblastoma and ependymoma cell lines (Fig. 1b). Remarkably, the intensity of the $5 \mathrm{caC}$ staining differed rather extensively between the paediatric brain tumour cell lines (Fig. 1b). Moreover, whereas most of the BXD-1425EPN, UW228-3 and Daoy cells exhibited similar levels of $5 \mathrm{caC}$ signal, the intensity of $5 \mathrm{caC}$ staining varied from strong ( $30 \%$ of cells in culture) to undetectable ( $70 \%$ of cells) in DKFZ-EP1NS cells (Fig. 1c, d).

We previously characterised the dynamics of $5 \mathrm{caC}$ levels in mouse embryonic brain tissue and showed that this mark transiently accumulates during lineage specification of neural stem cells peaking around 12.5-13.5 days post coitum (dpc) [27]. Interestingly, we found that $5 \mathrm{hmC}$ and $5 \mathrm{caC}$ were distributed in a semi-overlapping manner in the majority of $13.5 \mathrm{dpc}$ murine brain cells, which

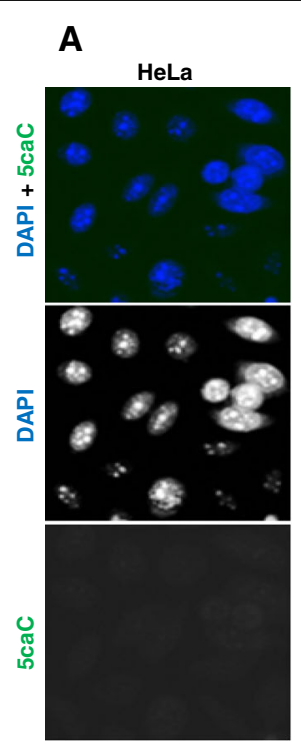

C
B

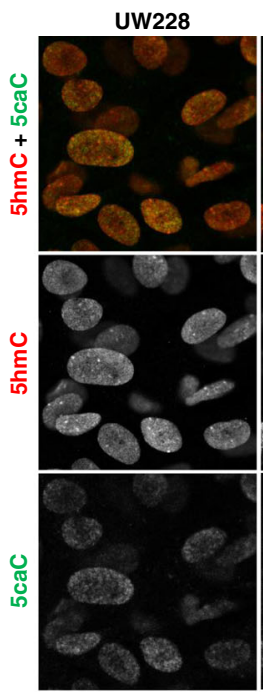

DKFZ-EP1NS

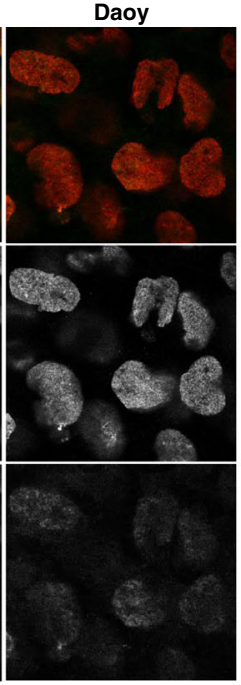

.

D
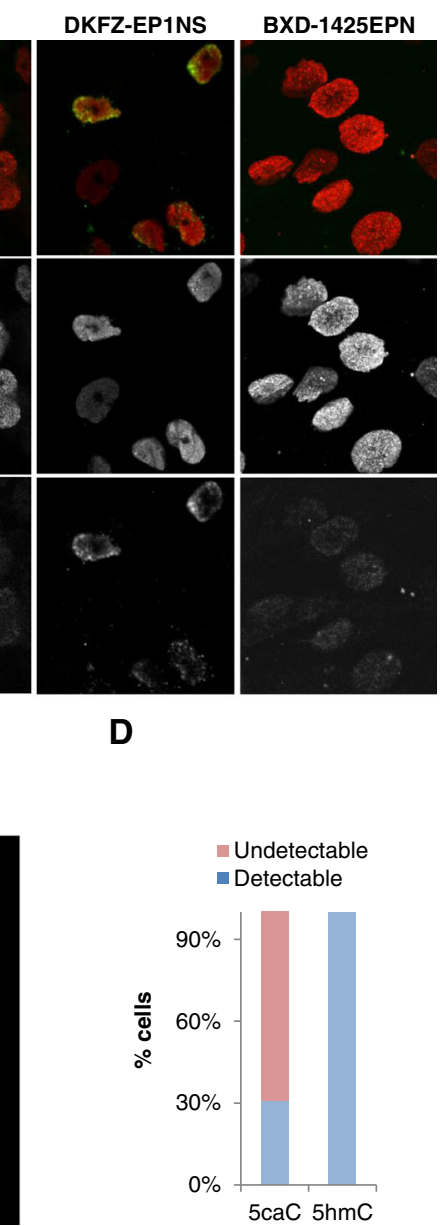

Fig. 1 Paediatric medulloblastoma and ependymoma cell lines exhibit immunochemically detectable levels of $5 \mathrm{hmC}$ and $5 \mathrm{caC}$. $\mathbf{a}$, b Co-detection of $5 \mathrm{caC}$ with DAPI (a) and $5 \mathrm{hmC}(\mathbf{b})$ in HeLa cells and indicated paediatric brain tumour cell lines. Merged views and individual channels are shown. The cell cultures were stained in parallel at the same experimental conditions and were imaged at identical settings. c Co-immunostaining of $5 \mathrm{hmC}$ and $5 \mathrm{caC}$ in two representative DKFZ-EP1NS cells with different levels of $5 \mathrm{caC}$ signal (designated as detectable for the top nucleus and undetectable for the bottom nucleus) used for the categorization of $5 \mathrm{caC}$ staining presented in $\mathbf{d}$. $\mathbf{d}$ Proportions of DKFZ-EP1NS cells with detectable or undetectable levels of $5 \mathrm{caC}$ and $5 \mathrm{hmC}$ signal 
suggested that the oxidation of $5 \mathrm{mC}$ to $5 \mathrm{caC}$ is limited to specific genomic regions in these cells [27]. Based on these results, we decided to compare the nuclear distribution of $5 \mathrm{hmC}$ and $5 \mathrm{caC}$ in paediatric brain tumours with that of the cells of the murine embryonic brain at $13.5 \mathrm{dpc}$ stage. Analysis of our confocal images revealed that, unlike in the cells of mouse embryonic brain, $5 \mathrm{hmC}$ and $5 \mathrm{caC}$ display high degrees of spatial overlap in the nuclei of the medulloblastoma and ependymoma cell lines we tested (Figs. 2a-e and 3a-e). Thus, 2.5XD signal intensity profiles were virtually identical for $5 \mathrm{hmC}$ and $5 \mathrm{caC}$ in the paediatric brain tumour cell lines (Figs. $2 \mathrm{a}$ and $3 \mathrm{a}$ ); and signal intensity profiles for both modifications were mimicking each other in ependymoma and medulloblastoma cells (Figs. $2 \mathrm{~b}-\mathrm{e}$ and $3 \mathrm{~b}-\mathrm{e}$ ), suggesting that $5 \mathrm{mC}$ oxidation to $5 \mathrm{caC}$ occurs genome-widely in these cell lines.

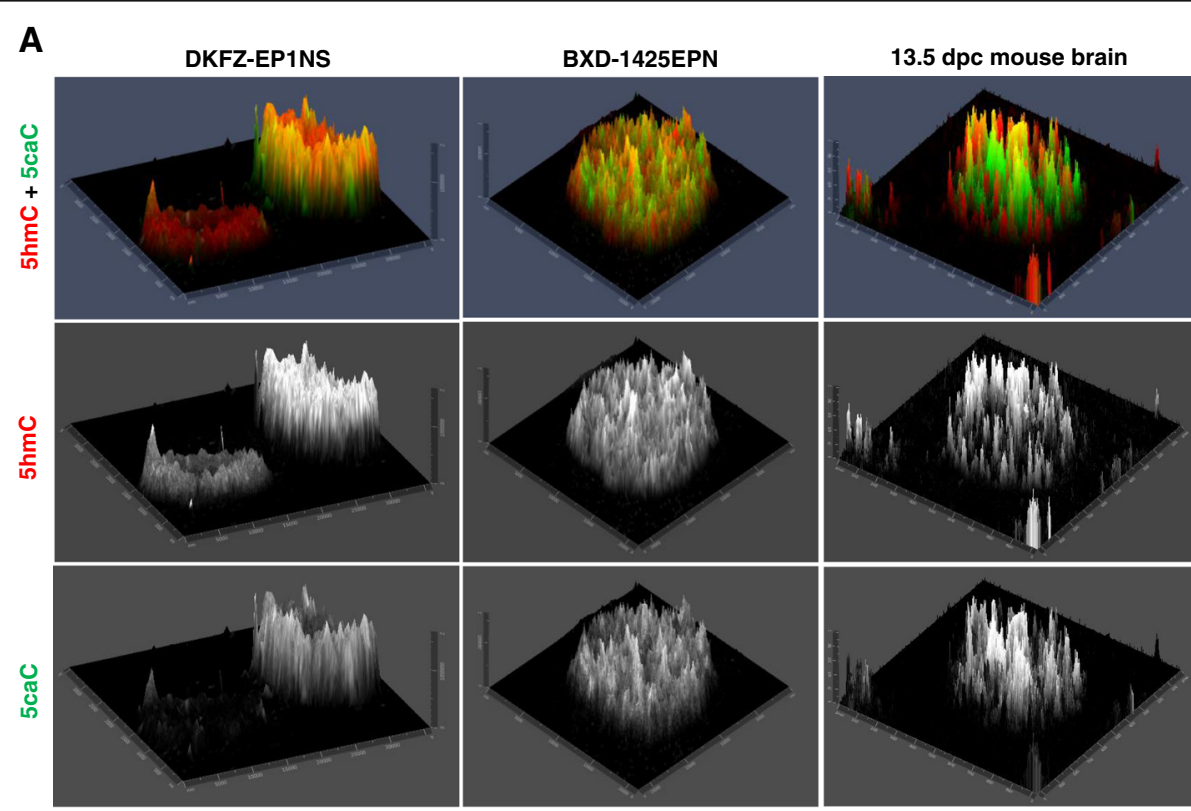

B

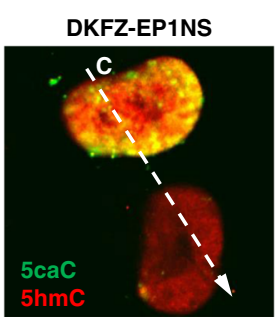

D

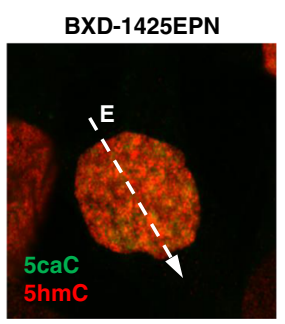

C

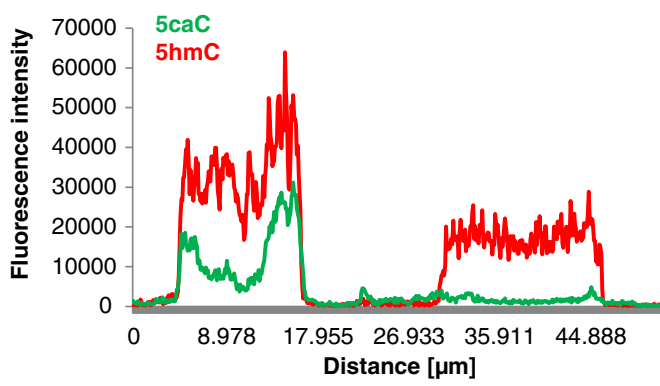

E

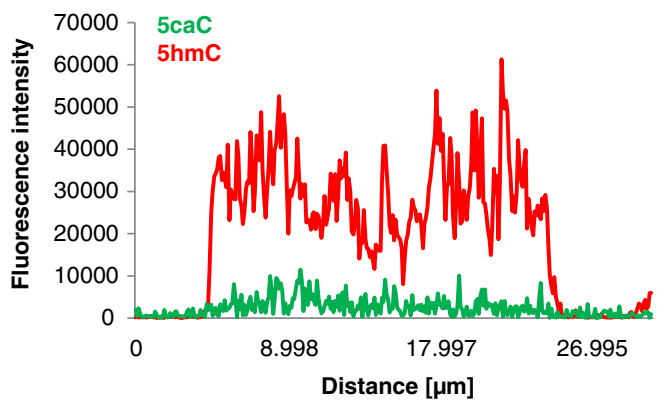

Fig. 2 Nuclear localization of $5 \mathrm{caC}$ and $5 \mathrm{hmC}$ in ependymoma cell lines. a 2.5XD 5caC and 5hmC signal intensity plots of the nuclei of two DKFZ-EP1NS cells with different levels of $5 \mathrm{caC}$ staining and a representative BXD-1425EPN nucleus compared with 2.5XD 5caC/5hmC signal intensity plot of a representative nucleus of a $13.5 \mathrm{dpc}$ mouse brain cell. Merged views and individual channels are shown. b-e Merged views of the confocal images of $5 \mathrm{caC}$ and $5 \mathrm{hmC}$ immunostaining in representative nuclei of DKFZ-EP1NS and BXD-1425EPN cells (b, d) with arrows designating nuclear regions used for generation of the signal intensity profiles shown in $\mathbf{c}$ and $\mathbf{e}$ 


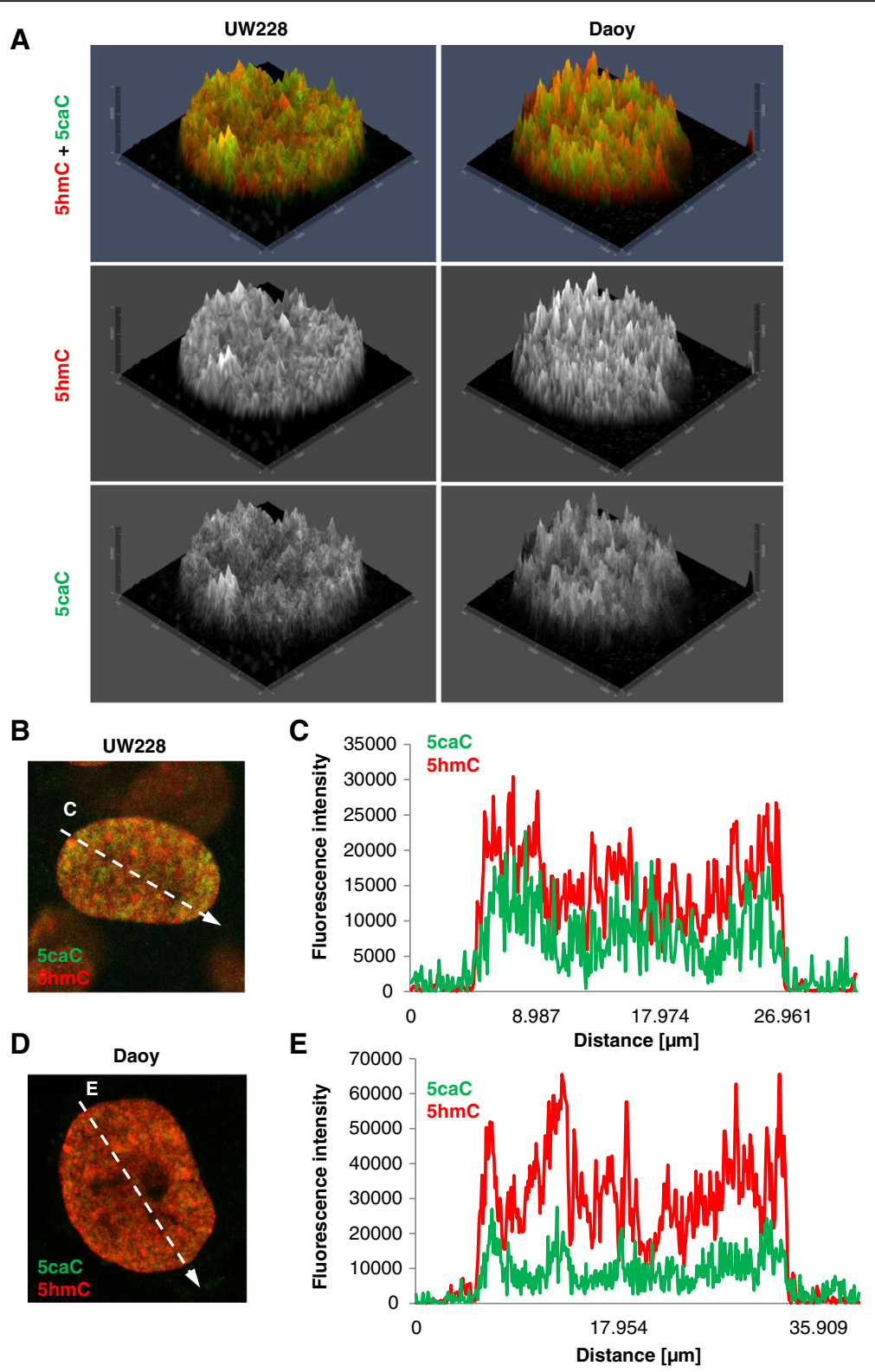

Fig. 3 Nuclear localization of $5 \mathrm{caC}$ and $5 \mathrm{hmC}$ in medulloblastoma cell lines. a 2.5XD $5 \mathrm{caC}$ and $5 \mathrm{hmC}$ signal intensity plots of the representative nuclei of UW228-3 and Daoy cells. Merged views and individual channels are shown. $\mathbf{b}-\mathbf{e}$ Merged views of the confocal images of $5 \mathrm{caC}$ and $5 \mathrm{hmC}$ immunostaining in representative nuclei of UW228-3 and Daoy cells $(\mathbf{b}$, $\mathbf{d})$ with arrows designating nuclear regions used for generation of the signal intensity profiles shown in $\mathbf{c}$ and $\mathbf{e}$

Next, we attempted to compare the intensities of $5 \mathrm{hmC}$ and $5 \mathrm{caC}$ signals between the four tested paediatric brain tumour cell lines employing analysis of the individual signal intensity profiles and quantification of the staining intensities in multiple cells (Fig. 4a, b). Both approaches demonstrated that, whereas the levels of $5 \mathrm{hmC}$ signal were comparable between all the cell lines, $5 \mathrm{caC}$ signal in a subpopulation of DKFZ-EP1NS cells positive for this modification (DKFZ-EP1NS H) was significantly higher $(p<0.01$ to $p<0.001)$ compared with other paediatric brain tumour cell lines (Fig. 4b). Importantly, the levels of $5 \mathrm{caC}$ immunostaining did not correlate with $5 \mathrm{hmC}$ signal intensity in the SHH medulloblastoma and ependymoma cell lines (Fig. 4b). To get an insight into potential molecular mechanisms for the $5 \mathrm{caC}$ enrichment in medulloblastoma and ependymoma cells, we examined the levels of TET1/2/ 3 and TDG transcripts in the four paediatric brain tumour cell lines and HeLa cells. These experiments revealed that neither TDG nor TET3 expression was substantially altering between all the five tested cell lines (Fig. 4c). In contrast, expression of TET2 and TET1 was generally higher (e.g. 2.37-fold for BXD-1425EPN and 4.14-fold for DKFZ- 

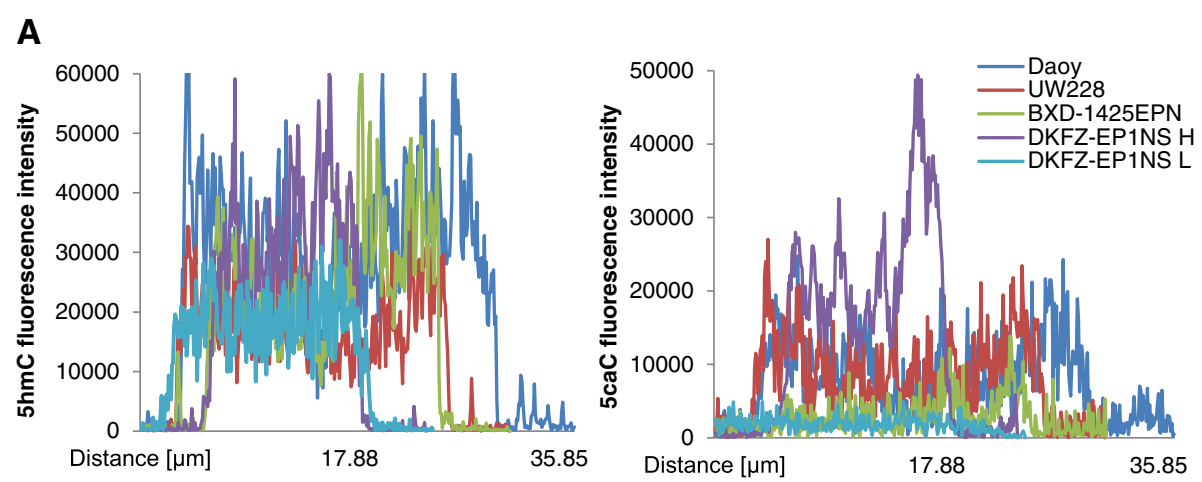

B
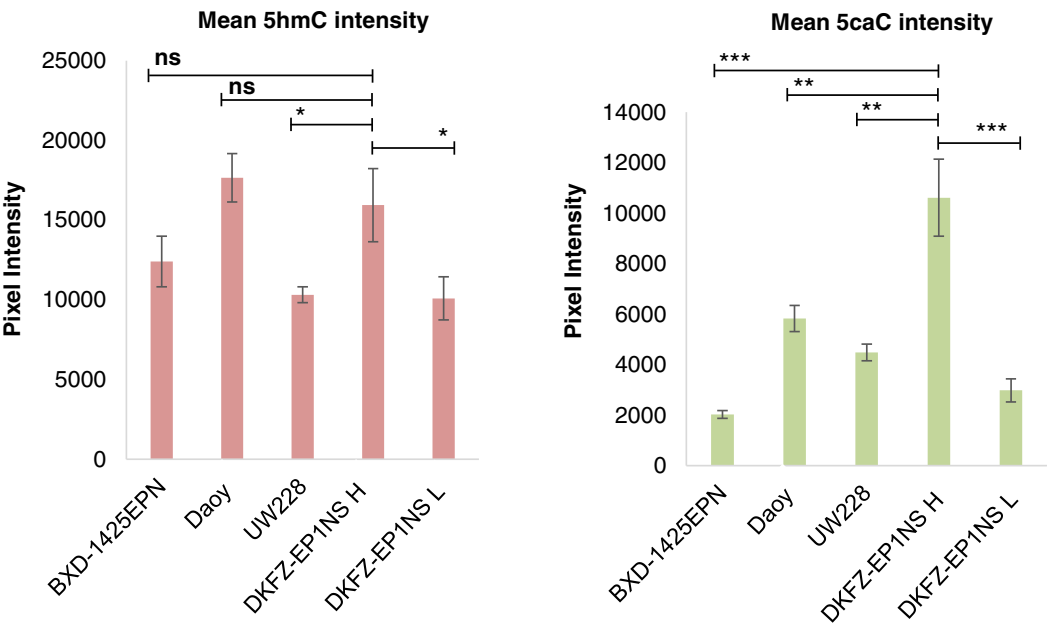

C
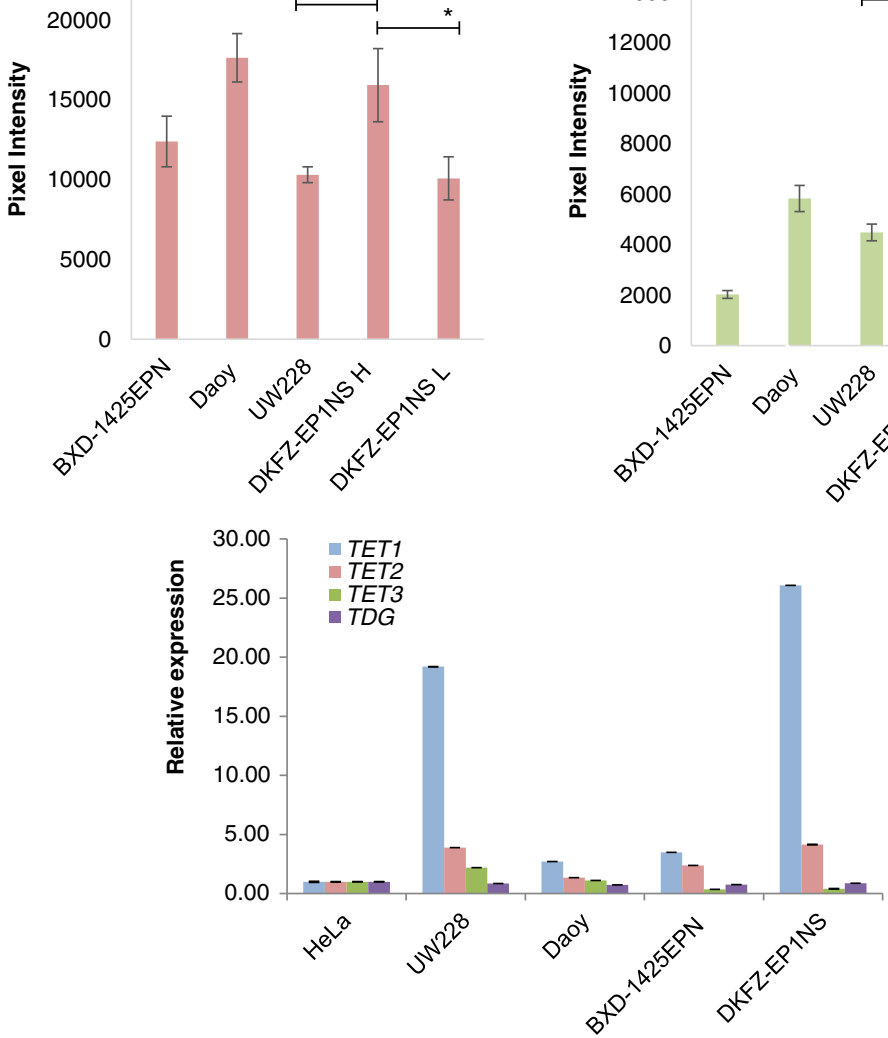

Fig. $45 \mathrm{caC}$ enrichment correlates with elevated levels of TET1 transcript in paediatric brain tumour cell lines. a Overlays of 5hmC (left) and 5caC (right) signal intensity profiles for representative nuclear regions of the indicated paediatric brain tumour cells. Signal intensity profiles for DKFZ-EP1NS cells with high/detectable (DKFZ-EP1NS H) and low/undetectable (DKFZ-EP1NS L) $5 \mathrm{caC}$ signals are shown separately. b Quantification of 5hmC and 5caC signals in the indicated ependymoma and medulloblastoma cell lines. Mean values of the average intensities of eight signal intensity profiles for each cell line/population are shown. DKFZ-EP1NS H cells with high/detectable $5 \mathrm{caC}$, DKFZ-EP1NS $L$ cells with low/undetectable $5 \mathrm{caC} .{ }^{* * *} p<0.001 ;{ }^{* *} p<0.01$; ${ }^{*} p<0.05$; $n$ n not significant. c Relative expression of Tet1/2/3 and TDG transcripts in the indicated paediatric brain tumour cell lines and HeLa cells. Experimental error is shown as SEM

EP1NS cells for TET2) in the brain tumour cell lines compared with HeLa cells. However, the levels of TET1 transcript exhibited the most dramatic increase in DKFZEP1NS and UW228-3 cells differing from HeLa in 26- and 19-fold correspondingly (Fig. 4c). Remarkably, the elevated levels of TET1 expression in DKFZ-EP1NS and UW228-3 corresponded to strong $5 \mathrm{caC}$ enrichment we observed in these cells.

\section{Discussion}

In a recently published review of TET1 functions in cancer, the authors came to conclusion that this protein has 
a dual role in tumorigenesis [5]. Thus, according to a number of studies, TET1 expression is decreased in different types of malignant tissue [16, 28, 29]. Moreover, suppression of TET1 expression was reported to be associated with facilitated cell invasion and metastasis $[30,31]$ and even to play a critical role in KRAS-induced tumour transformation [32]. Contrasting with these reports, there is experimental evidence that TET1 acts as an oncogene in MLL-rearranged leukaemia and breast tumour malignancies [33, 34]. In this context, our observation that the levels of TET1 transcript are elevated in medulloblastoma and ependymoma cells may imply that this protein is involved in pathogenesis of the paediatric brain tumours via demethylation of the regulatory elements of the oncogenes promoting initiation and/or progression of these types of cancer.

Medulloblastoma and ependymoma represent the two most common forms of malignant paediatric brain tumours. Both tumour types have recently been categorised into clinically relevant molecular subgroups [35, 36], which can be recapitulated by methylation analyses supporting the hypothesis that epigenetic drivers may play a key role in pathogenesis of these tumour types [37, 38]. Thus, the current classification of medulloblastomas include Wnt, sonic hedgehog (SHH) and group 3 and 4 subtypes [39, 40]. The pairs of cell lines used in this study represent the most aggressive subgroups of each tumour type that respond poorly to current therapeutic approaches. UW228-3 and Daoy are both SHH pathwayactivated lines harbouring a mutant TP53 gene (SHH-activated, TP53 mutant) [39]. BXD-1425EPN and DKFZEP1NS on the other hand represent a subgroup of ependymomas that carry a C11orf95-RELA fusion oncogene which results in activation of the NF- $\mathrm{kB}$ signalling pathway [40]. Remarkably, TP53 function has also recently been shown to be abrogated in the majority of RELA ependymomas where it is associated with particularly poor outcome [41]. In addition, both ependymomas and $\mathrm{SHH}$ medulloblastomas have been demonstrated to maintain a population of stem-like cells [42, 43]. These cells express cancer stem cell and neural stem cell markers CD133 and Nestin [42, 44-46]. Highly tumorigenic and metastatic ependymoma cell line DKFZ-EP1NS, which demonstrates in vivo primary tumour recapitulation ability in orthotopic xenograft models, expresses both these stem cell markers together with CD15 and ALDH [24]. Importantly, expression of CD15 and ALDH is also a feature shared by aggressive SHH medulloblastoma cell lines UW228-3 and Daoy [24, 47]. Correspondingly, deregulation of signalling pathways important for embryonic brain development (e.g. SHH, Wnt and Notch pathways) appears to be a hallmark of both ependymomas and medulloblastomas and to play essential role in pathogenesis of these tumours [22]. Likewise, in line with anticipated significance of Tet proteins for neuro- and gliogenesis [27], the aberrantly increased TET1-dependent $5 \mathrm{mC}$ oxidation may represent one of the epigenetic signatures of these cancers reflecting their likely neural progenitor/stem cell origin.

Interestingly, although $5 \mathrm{caC}$ enrichment corresponded to remarkably high levels of TET1 mRNA in DKFZEP1NS and UW228-3 cell lines in our experiments, in Daoy cells, high intensities of both $5 \mathrm{hmC}$ and $5 \mathrm{caC}$ staining were paralleled by levels of TET1/2/3 and TDG transcripts comparable with those in HeLa cells where $5 \mathrm{caC}$ was not detectable by immunochemistry under our conditions. This suggests that either specific posttranscriptional mechanisms of regulation of TET1/2/3 expression may be operative in this cell line or oxi-mCs may be stabilised there due to certain features of DNA methyltransferases, oxi-mCs-interacting proteins and/or components of BER machinery specific for Daoy cells.

Although the presence of $5 \mathrm{fC}$ and $5 \mathrm{caC}$ in genomic DNA is often perceived as an indication of active TDGdependent DNA demethylation, a growing body of experimental evidence suggests that all the oxi-mCs may play their own specific roles in gene regulation [27, 48-50]. Thus, developmental dynamics of $5 \mathrm{fC}$ is different from that of $5 \mathrm{hmC}$ [50], and different oxi-mCs are associated with distinct sets of regulatory sequences in the genome [27, 51]. Moreover, specific groups of candidate "reader" proteins have been identified for each of the oxi-mCs using mass spectrometry-based approaches [52]. Interestingly, the lists of potential "reader" proteins for $5 \mathrm{fC}$ and $5 \mathrm{caC}$ include a number of transcription factors, chromatin remodelling proteins and histonemodifying enzymes [52]. Therefore, our data revealing the genome-wide $5 \mathrm{caC}$ enrichment in UW228-3, Daoy and a subpopulation of DKFZ-EP1NS cells suggest that the presence of this modification in regulatory genomic regions may not only be linked with their demethylation but also affect transcriptional activity of the corresponding genes in these cells via $5 \mathrm{caC}$-dependent recruitment of transcriptional factors or chromatin modifying complexes, contributing to the malignant phenotypes of the paediatric brain tumour cell lines.

Further studies should evaluate functional significance of increased levels of TET1 and $5 \mathrm{caC}$ in medulloblastoma and ependymoma providing new information on the pathogenesis and potentially leading to development of novel targets for therapy of these brain tumours. In addition, UW228-3, Daoy and DKFZ-EP1NS cells may represent a suitable experimental model to study the molecular mechanisms of Tet-dependent $5 \mathrm{mC}$ oxidation and potential roles of oxi-mCs in transcriptional regulation.

Abbreviations

Tet1: Ten-eleven translocation protein 1 


\section{Acknowledgements}

We thank Robert Markus (University of Nottingham) for his help with confocal imaging.

\section{Funding}

The work was supported by the MSc course in Stem Cell Technology (University of Nottingham) and BBSRC (BB/N005759/1 to AR).

\section{Availability of data and materials}

The datasets obtained and/or analysed during the current study are available from the corresponding author upon reasonable request.

\section{Authors' contributions}

AshR and LL performed the immunostaining experiments, confocal microscopy, GPCR and statistical analysis. AR and BC conceived the study, participated in its design and coordination and drafted the manuscript together with AshR. All authors read and approved the final manuscript.

\section{Competing interests}

The authors declare that they have no competing interests.

\section{Consent for publication}

Not applicable.

\section{Ethics approval and consent to participate}

Not applicable.

\section{Received: 21 September 2016 Accepted: 19 December 2016} Published online: 13 February 2017

\section{References}

1. Jones PA, Baylin SB. The fundamental role of epigenetic events in cancer. Nat Rev Genet. 2002;3:415-28.

2. Goding CR, Pei D, Lu X. Cancer: pathological nuclear reprogramming? Nat Rev Cancer. 2014;14:568-73.

3. Ehrlich M, Lacey M. DNA hypomethylation and hemimethylation in cancer. Adv Exp Med Biol. 2013;754:31-56.

4. Dawson MA, Kouzarides T. Cancer epigenetics: from mechanism to therapy. Cell. 2012;150:12-27.

5. Tian YP, Zhu YM, Sun XH, Lai MD. Multiple functions of ten-eleven translocation 1 during tumorigenesis. Chin Med J (Engl). 2016;129:1744-51.

6. Tahiliani M, Koh KP, Shen Y, Pastor WA, Bandukwala H, Brudno Y, et al. Conversion of 5-methylcytosine to 5-hydroxymethylcytosine in mammalian DNA by MLL partner TET1. Science. 2009;5929:930-5.

7. He YF, Li BZ, Li Z, Liu P, Wang Y, Tang Q, et al. Tet-mediated formation of 5 carboxylcytosine and its excision by TDG in mammalian DNA. Science. 2011; 6047:1303-7.

8. Ito S, Shen L, Dai Q, Wu SC, Collins LB, Swenberg JA, et al. Tet proteins can convert 5-methylcytosine to 5-formylcytosine and 5-carboxylcytosine. Science. 2011;6047:1300-3.

9. Ficz G, Hore TA, Santos F, Lee HJ, Dean W, Arand J, et al. FGF signaling inhibition in ESCs drives rapid genome-wide demethylation to the epigenetic ground state of pluripotency. Cell Stem Cell. 2013;13:351-9.

10. Iurlaro M, Ficz G, Oxley D, Raiber EA, Bachman M, Booth MJ, et al. A screen for hydroxymethylcytosine and formylcytosine binding proteins suggests functions in transcription and chromatin regulation. Genome Biol. 2013;14:R119.

11. Maiti A, Drohat AC. Thymine DNA glycosylase can rapidly excise 5formylcytosine and 5-carboxylcytosine: potential implications for active demethylation of CpG sites. J Biol Chem. 2011;286:35334-8.

12. Wu H, Zhang Y. Mechanisms and functions of Tet protein-mediated 5methylcytosine oxidation. Genes Dev. 2011;25:2436-52.

13. Ficz G, Gribben JG. Loss of 5-hydroxymethylcytosine in cancer: cause or consequence? Genomics. 2014;104:352-7.

14. Haffner MC, Chaux A, Meeker AK, Esopi DM, Gerber J, Pellakuru LG, et al. Global 5-hydroxymethylcytosine content is significantly reduced in tissue stem/progenitor cell compartments and in human cancers. Oncotarget. 2011;2:627-37

15. Jin SG, Jiang Y, Qiu R, Rauch TA, Wang Y, Schackert G, et al. 5Hydroxymethylcytosine is strongly depleted in human cancers but its levels do not correlate with IDH1 mutations. Cancer Res. 2011;71:7360-5.
16. Kudo Y, Tateishi K, Yamamoto K, Yamamoto S, Asaoka Y, ljichi H, et al. Loss of 5-hydroxymethylcytosine is accompanied with malignant cellular transformation. Cancer Sci. 2012;103:670-6.

17. Lian CG, Xu Y, Ceol C, Wu F, Larson A, Dresser K, et al. Loss of 5hydroxymethylcytosine is an epigenetic hallmark of melanoma. Cell. 2012; 150:1135-46.

18. Eleftheriou M, Pascual AJ, Wheldon LM, Perry C, Abakir A, Arora A, Johnson AD, Auer DT, Ellis IO, Madhusudan S, Ruzov A. 5-Carboxylcytosine levels are elevated in human breast cancers and gliomas. Clin Epigenetics. 2015;7:88.

19. Kraus TF, Greiner A, Steinmaurer M, Dietinger V, Guibourt V, Kretzschmar HA Genetic characterization of ten-eleven-translocation methylcytosine dioxygenase alterations in human glioma. J Cancer. 2015;6:832-42.

20. Bian EB, Zong G, Xie YS, Meng XM, Huang C, Li J, Zhao B. TET family proteins: new players in gliomas. J Neurooncol. 2014;116:429-35.

21. Takai H, Masuda K, Sato T, Sakaguchi Y, Suzuki T, Suzuki T, Koyama-Nasu R, Nasu-Nishimura Y, Katou Y, Ogawa H, Morishita Y, Kozuka-Hata H, Oyama M, Todo T, Ino Y, Mukasa A, Saito N, Toyoshima C, Shirahige K, Akiyama T. 5Hydroxymethylcytosine plays a critical role in glioblastomagenesis by recruiting the CHTOP-methylosome complex. Cell Rep. 2014:9:48-60.

22. de Bont JM, Packer RJ, Michiels EM, den Boer ML, Pieters R. Biological background of pediatric medulloblastoma and ependymoma: a review from a translational research perspective. Neuro Oncol. 2008;10:1040-60.

23. Yu L, Baxter PA, Voicu H, Gurusiddappa S, Zhao Y, Adesina A, Man TK, Shu Q, Zhang YJ, Zhao XM, Su JM, Perlaky L, Dauser R, Chintagumpala M, Lau CC, Blaney SM, Rao PH, Leung HC, Li XN. A clinically relevant orthotopic xenograft model of ependymoma that maintains the genomic signature of the primary tumor and preserves cancer stem cells in vivo. Neuro Oncol. 2010;12:580-94.

24. Milde T, Kleber S, Korshunov A, Witt H, Hielscher T, Koch P, Kopp HG, Jugold M, Deubzer HE, Oehme I, Lodrini M, Gröne HJ, Benner A, Brüstle O, Gilbertson RJ, von Deimling A, Kulozik AE, Pfister SM, Martin-Villalba A, Witt O. A novel human high-risk ependymoma stem cell model reveals the differentiation-inducing potential of the histone deacetylase inhibitor Vorinostat. Acta Neuropathol. 2011;122:637-50.

25. Tempest PR, Stratton MR, Cooper CS. Structure of the met protein and variation of met protein kinase activity among human tumour cell lines. $\mathrm{Br} J$ Cancer. 1988:58:3-7.

26. Keles GE, Berger MS, Srinivasan J, Kolstoe DD, Bobola MS, Silber JR. Establishment and characterization of four human medulloblastoma-derived cell lines. Oncol Res. 1995;7:493-503.

27. Wheldon LM, Abakir A, Ferjentsik Z, Dudnakova T, et al. Transient accumulation of 5-carboxylcytosine indicates involvement of active demethylation in lineage specification of neural stem cells. Cell Rep. 2014;7:1353-61.

28. Ichimura N, Shinjo K, An B, Shimizu Y, Yamao K, Ohka F, Katsushima K, Hatanaka A, Tojo M, Yamamoto E, Suzuki H, Ueda M, Kondo Y. Aberrant TET1 methylation closely associated with CpG island methylator phenotype in colorectal cancer. Cancer Prev Res (Phila). 2015;8:702-11.

29. Rawłuszko-Wieczorek AA, Siera A, Horbacka K, Horst N, Krokowicz P, Jagodzińsk PP. Clinical significance of DNA methylation mRNA levels of TET family members in colorectal cancer. J Cancer Res Clin Oncol. 2015;141:1379-92.

30. Hsu CH, Peng KL, Kang ML, Chen YR, Yang YC, Tsai CH, Chu CS, Jeng YM, Chen YT, Lin FM, Huang HD, Lu YY, Teng YC, Lin ST, Lin RK, Tang FM, Lee SB, Hsu HM, Yu JC, Hsiao PW, Juan $\sqcup$. TET1 suppresses cancer invasion by activating the tissue inhibitors of metalloproteinases. Cell Rep. 2012:2:568-79.

31. Park SJ, Lee BR, Kim HS, Ji YR, Sung YH, ShikChoi K, Park HD, Kim SH, Kim MO, Ryoo ZY. Inhibition of migration and invasion by TET-1 overexpression in human lung carcinoma H460 cells. Oncol Res. 2016;23:89-98.

32. Wu BK, Brenner C. Suppression of TET1-dependent DNA demethylation is essential for KRAS-mediated transformation. Cell Rep. 2014;9:1827-40.

33. Huang $H$, Jiang $X$, Li Z, Li Y, Song CX, He C, Sun M, Chen P, Gurbuxani S, Wang J, Hong GM, Elkahloun AG, Arnovitz S, Wang J, Szulwach K, Lin L, Street C, Wunderlich M, Dawlaty M, Neilly MB, Jaenisch R, Yang FC, Mulloy JC, Jin P, Liu PP, Rowley JD, Xu M, He C, Chen J. TET1 plays an essential oncogenic role in MLL-rearranged leukemia. Proc Natl Acad Sci U S A. 2013;110:11994-9.

34. Wu MZ, Chen SF, Nieh S, Benner C, Ger LP, Jan Cl, Ma L, Chen CH, Hishida T, Chang HT, Lin YS, Montserrat N, Gascon P, Sancho-Martinez I, Izpisua Belmonte JC. Hypoxia drives breast tumor malignancy through a TET-TNFap38-MAPK signaling axis. Cancer Res. 2015;75:3912-24.

35. Johnson RA, Wright KD, Poppleton H, Mohankumar KM, Finkelstein D, Pounds SB, Rand V, Leary SE, White E, Eden C, Hogg T, Northcott P, Mack S, Neale G, Wang YD, Coyle B, Atkinson J, DeWire M, Kranenburg TA, Gillespie Y, Allen JC, Merchant T, Boop FA, Sanford RA, Gajjar A, Ellison DW, Taylor MD, Grundy RG, 
Gilbertson RJ. Cross-species genomics matches driver mutations and cell compartments to model ependymoma. Nature. 2010;466:632-6.

36. Taylor MD, Northcott PA, Korshunov A, Remke M, Cho YJ, Clifford SC, Eberhart CG, Parsons DW, Rutkowski S, Gajjar A, Ellison DW, Lichter P, Gilbertson RJ, Pomeroy SL, Kool M, Pfister SM. Molecular subgroups of medulloblastoma: the current consensus. Acta Neuropathol. 2012;123:465-72.

37. Pajtler KW, Witt H, Sill M, Jones DT, Hovestadt V, Kratochwil F, Wani K, Tatevossian R, Punchihewa C, Johann P, Reimand J, Warnatz HJ, Ryzhova M, Mack S, Ramaswamy V, Capper D, Schweizer L, Sieber L, Wittmann A, Huang $Z$, van Sluis P, Volckmann R, Koster J, Versteeg R, Fults D, Toledano H, Avigad S, Hoffman LM, Donson AM, Foreman N, Hewer E, Zitterbart K, Gilbert M, Armstrong TS, Gupta N, Allen JC, Karajannis MA, Zagzag D, Hasselblatt M, Kulozik AE, Witt O, Collins VP, von Hoff K, Rutkowski S, Pietsch T, Bader G, Yaspo ML, von Deimling A, Lichter P, Taylor MD, Gilbertson R, Ellison DW, Aldape K, Korshunov A, Kool M, Pfister SM. Molecular classification of ependymal tumors across all CNS compartments, histopathological grades, and age groups. Cancer Cell. 2015;27:728-43.

38. Hovestadt V, Jones DT, Picelli S, Wang W, Kool M, Northcott PA, Sultan M, Stachurski K, Ryzhova M, Warnatz HJ, Ralser M, Brun S, Bunt J, Jäger N, Kleinheinz K, Erkek S, Weber UD, Bartholomae CC, von Kalle C, Lawerenz C, Eils J, Koster J, Versteeg R, Milde T, Witt O, Schmidt S, Wolf S, Pietsch T, Rutkowski S, Scheurlen W, Taylor MD, Brors B, Felsberg J, Reifenberger G, Borkhardt A, Lehrach H, Wechsler-Reya RJ, Eils R, Yaspo ML, Landgraf $P$, Korshunov A, Zapatka M, Radlwimmer B, Pfister SM, Lichter P. Decoding the regulatory landscape of medulloblastoma using DNA methylation sequencing. Nature. 2014;510:537-41.

39. Ramaswamy V, Remke M, Bouffet E, Bailey S, Clifford SC, Doz F, Kool M, Dufour C, Vassal G, Milde T, Witt O, von Hoff K, Pietsch T, Northcott PA, Gajjar A, Robinson GW, Padovani L, André N, Massimino M, Pizer B, Packer R, Rutkowski S, Pfister SM, Taylor MD, Pomeroy SL. Risk stratification of childhood medulloblastoma in the molecular era: the current consensus. Acta Neuropathol. 2016;131:821-31.

40. Parker M, Mohankumar KM, Punchihewa C, Weinlich R, Dalton JD, Li Y, Lee R, Tatevossian RG, Phoenix TN, Thiruvenkatam R, White E, Tang B, Orisme W, Gupta K, Rusch M, Chen X, Li Y, Nagahawhatte P, Hedlund E, Finkelstein D, Wu G, Shurtleff S, Easton J, Boggs K, Yergeau D, Vadodaria B, Mulder HL, Becksfort J, Gupta P, Huether R, Ma J, Song G, Gajjar A, Merchant T, Boop F, Smith AA, Ding L, Lu C, Ochoa K, Zhao D, Fulton RS, Fulton LL, Mardis ER, Wilson RK, Downing JR, Green DR, Zhang J, Ellison DW, Gilbertson RJ. C11orf95-RELA fusions drive oncogenic NF-KB signalling in ependymoma. Nature. 2014;506:451-5.

41. Tzaridis T, Milde T, Pajtler KW, Bender S, Jones DT, Müller S, Wittmann A, Schlotter M, Kulozik AE, Lichter P, Collins VP, Witt O, Kool M, Korshunov A, Pfister SM, Witt H. Low-dose actinomycin-D treatment re-establishes the tumoursuppressive function of P53 in RELA-positive ependymoma. Oncotarget. 2016. doi: 10.18632/oncotarget.11452.

42. Milde T, Hielscher T, Witt H, Kool M, Mack SC, Deubzer HE, Oehme I, Lodrini M, Benner A, Taylor MD, von Deimling A, Kulozik AE, Pfister SM, Witt O, Korshunov A. Nestin expression identifies ependymoma patients with poor outcome. Brain Pathol. 2012;22:848-60.

43. Vanner RJ, Remke M, Gallo M, Selvadurai HJ, Coutinho F, Lee L, Kushida M, Head R, Morrissy S, Zhu X, Aviv T, Voisin V, Clarke ID, Li Y, Mungall AJ, Moore RA, Ma Y, Jones SJ, Marra MA, Malkin D, Northcott PA, Kool M, Pfister SM, Bader G, Hochedlinger K, Korshunov A, Taylor MD, Dirks PB. Quiescent sox2(+) cells drive hierarchical growth and relapse in sonic hedgehog subgroup medulloblastoma. Cancer Cell. 2014;26:33-47.

44. Taylor MD, Poppleton H, Fuller C, Su X, Liu Y, Jensen P, Magdaleno S, Dalton J, Calabrese C, Board J, Macdonald T, Rutka J, Guha A, Gajjar A, Curran T, Gilbertson RJ. Radial glia cells are candidate stem cells of ependymoma. Cancer Cell. 2005;8:323-35.

45. Chen KH, Hsu CC, Song WS, Huang CS, Tsai CC, Kuo CD, Hsu HS, Tsai TH, Tsai CY, Woung LC, Chiou SH, Lu KH, Chen YW. Celecoxib enhances radiosensitivity in medulloblastoma-derived CD133-positive cells. Childs Nerv Syst. 2010;26:1605-12.

46. Chang CJ, Chiang CH, Song WS, Tsai SK, Woung LC, Chang CH, Jeng SY, Tsai CY, Hsu CC, Lee HF, Huang CS, Yung MC, Liu JH, Lu KH. Inhibition of phosphorylated STAT3 by cucurbitacin I enhances chemoradiosensitivity in medulloblastoma-derived cancer stem cells. Childs Nerv Syst. 2012;28:363-73.
47. Dietl S, Schwinn S, Dietl S, Riedel S, Deinlein F, Rutkowski S, von Bueren AO, Krauss J, Schweitzer T, Vince GH, Picard D, Eyrich M, Rosenwald A, Ramaswamy V, Taylor MD, Remke M, Monoranu CM, Beilhack A, Schlegel PG, Wölfl M. MB3W1 is an orthotopic xenograft model for anaplastic medulloblastoma displaying cancer stem cell- and group 3-properties. BMC Cancer. 2016;16:115.

48. Tamanaha E, Guan S, Marks K, Saleh L. Distributive processing by the iron(II)/ a-ketoglutarate-dependent catalytic domains of the TET enzymes is consistent with epigenetic roles for oxidized 5-methylcytosine bases. J Am Chem Soc. 2016;138:9345-8.

49. Bachman M, Uribe-Lewis S, Yang X, Williams M, Murrell A, Balasubramanian S. 5-Hydroxymethylcytosine is a predominantly stable DNA modification. Nat Chem. 2014;6:1049-55.

50. Bachman M, Uribe-Lewis S, Yang X, Burgess HE, lurlaro M, Reik W, Murrell A, Balasubramanian S. 5-Formylcytosine can be a stable DNA modification in mammals. Nat Chem Biol. 2015;11:555-7.

51. Iurlaro M, McInroy GR, Burgess HE, Dean W, Raiber EA, Bachman M, Beraldi D, Balasubramanian S, Reik W. In vivo genome-wide profiling reveals a tissue-specific role for 5-formylcytosine. Genome Biol. 2016;17:141.

52. Song J, Pfeifer GP. Are there specific readers of oxidized 5-methylcytosine bases? Bioessays. 2016. doi: 10.1002/bies.201600126.

\section{Submit your next manuscript to BioMed Central and we will help you at every step:}

- We accept pre-submission inquiries

- Our selector tool helps you to find the most relevant journal

- We provide round the clock customer support

- Convenient online submission

- Thorough peer review

- Inclusion in PubMed and all major indexing services

- Maximum visibility for your research

Submit your manuscript at www.biomedcentral.com/submit
C Biomed Central 